\title{
THE EFFECT OF CHARACTER EDUCATION AND THE ROLE OF TEACHERS ON THE COMPETENCY OF STUDENTS IN ACCOUNTING AND FINANCE PROGRAM SMKN 1 TORAJA UTARA
}

\author{
Karuniawati ${ }^{1}$, Bernedheta Nadeak ${ }^{2 \square}$ \\ 1,2 Magister of Educational Administration/Management Study, Postgraduate Program Universitas \\ Kristen Indonesia, Jakarta
}

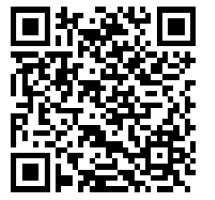

DOI: https://doi.org/10.29121/granthaalayah.v9.i2.2021.3525

Article Type: Research Article

Article Citation: Karuniawati, and Bernedheta Nadeak. (2021). THE EFFECT OF CHARACTER EDUCATION AND THE ROLE OF TEACHERS ON THE COMPETENCY OF STUDENTS IN ACCOUNTING AND FINANCE PROGRAM SMKN 1 TORAJA UTARA. International Journal of Research GRANTHAALAYAH, 9(2), 241-247. https://doi.org/10.29121/granthaa layah.v9.i2.2021.3525

Received Date: 30 January 2021

Accepted Date: 28 February 2021

Keywords:

Character Education

Teacher Role

Student Competence

Vocational High School

\section{ABSTRACT}

The World of Business and the World of Industry requires competent human resources and prioritizes human resources who have character according to company criteria. As a school that prepares students to enter the world of work, Vocational High School is required to answer the needs of the world of work. From this problem, this research was conducted to see the effect of character education and the role of teachers on the competence of students majoring in accounting and financial institutions at SMKN 1 Toraja Utara, using quantitative research methods. The research results showed a positive influence between character education and student competence shown in the sig results. Deviation from linearity of character education $0.641>0.05$, which means that there is a linear relationship between character education and student competence, further proof is done through a correlation test which shows a significant result of $0.00<0.05$ and a Pearson Correlation value of 0.715 , which means that there is a correlation between character education and student competence. With the degree of strong category relationship. Likewise, the teacher's role in student competence has a positive influence on sig results. Deviation from the linearity of character education is $0.333>0.05$, which means a linear relationship between the teacher's role and student competence. A correlation test is carried out which shows a significant result of $0.00<0.05$ and a Pearson Correlation value of 0.647 , meaning a correlation between the teacher's role and student competence with degrees strong category relationship. From the results of the F test, it can be concluded that there is a simultaneous influence of character education and the role of teachers on the competence of students in financial accounting expertise programs and institutions at SMKN 1 Toraja Utara, where Fcount is more significant than $F$ table $(20,798.3,33)$, with a significance value of $0,000 .<0.05$. Likewise, it can be seen from the coefficient of determination of 0.598 , which means that $59.8 \%$ of character education and the role of teachers affect student competence, while variations influence the remaining $40.2 \%$ in other variables. 
The Effect of Character Education and the Role of Teachers on the Competency of Students in Accounting and Finance Program SMKN 1 Toraja Utara

\section{INTRODUCTION}

In the era of the industrial revolution 4.0, Indonesia needs human resources in sufficient quantity and quality to support the development of a nation that aggressively boosts development on all fronts to balance competition with other countries globally. To meet the needs of adequate Human Resources (HR), the role of Education is vital, and schools are challenged to improve themselves in order to be able to meet HR needs [1], [2]. In the National Education System Law No. 20 of 2003, "national education functions in developing abilities and shaping character and forming a dignified national civilization to educate the nation's life."

"Education is a process carried out deliberately in order to foster the potentials of students as a provision for their life. The process referred to is in the form of knowledge transfer, developing skills, and giving examples of attitudes, so that later students are ready to live amid society and a religious nation and state. That readiness requires a sufficient provision of personality called character" [3], [4].

Secondary education institutions that teach skills characterized by strong characters are vocational secondary Education because vocational secondary Education is a secondary education that prioritizes the development of students' ability to do certain types of work and is related to the industrial world.

Vocational High School students prepare students to become human resources ready to work with good attitude, knowledge, and skills to meet the Business and Industrial World demands [5], [6], [7]. However, criticism often arises, stating that the resulting human resources are low not to carry out tasks in the industrial world. To answer this criticism, the teacher plays a strategic role in meeting students' needs through a quality learning process and prioritizes character building in each training course that is tucked into the Syllabus and lesson plan, which refers to the Minimum Completeness Standards. As a habituation process in the school environment, school is a picture where students gain knowledge and skills according to the expected majors and eventually become readyto-use human resources.

Character values at minimum completeness standards that vocational high school students must own are (1) religious, (2) honest, (3) self-confident, (4) respect for others, (5) compassion, (6) patient, (7) discipline, (8) politeness, (9) logical thinking, (10) critical thinking, (11) creative thinking, (12) innovative thinking, (13) competitive, (14) responsive, (15) analysis and (16) caring environment [8], [9]. Likewise, at State Vocational High School 1 (SMKN 1) Toraja Utara as the largest vocational school in North Toraja Regency and a Reference school that has a vision of producing superior human resources seeks to apply character education to every student in order to face the era of the industrial revolution 4.0, thus in line with President Jokowi's Program on Strengthening. Character Education as outlined in Presidential Decree No. 87 of 2017.

The teacher always plays a role in building student character, guiding students, and evaluating how character values can be carried out correctly. Likewise for vocational competence which is an absolute requirement for vocational students to face job competition, teachers train students in the field of vocational mastery they are engaged in to be competent and who can eventually enter the world of work [10], [11].

Teachers must be able to integrate with the work character learning process, and educators are expected to plan, implement and evaluate with learning assessments that fully integrate work character and vocational abilities [12]. Teachers are expected to choose learning methods and strategies that lead to the growth of positive characters that are in line with the expected competencies.

In the Accounting and Finance expertise program students are required to be able to work on financial reports accurately, quickly and can be accessed through the use of technology for all the data needed, students must have strong character values to integrate technology to manage financial numbers in order to produce accurate and appropriate financial reports [13], [14], [15]. With data quickly, of course, the character to be formed in this case is emphasized, the first is the honesty of students in managing data or numbers, the second is a discipline with a high work ethic and the third is creative thinking in solving every financial case in accordance with accounting principles, either manually or computerized or online, contained in each Core Competency and Basic Competency [16], [17]. Nevertheless, sometimes students do not use internet facilities to meet their learning needs, tend to delay the work and assignments given, and access inappropriate data as well as lack of student creativity in completing a case study in learning so that in each competency assessment of student practice the results are shallow [18], [19].

The competencies that students majoring in financial and institutional accounting must have are financial accounting practices for service companies, trade, and manufacture, and practice managing accounting computer applications [20], [21]. [22]. To measure the competence of graduates, the standards used are the results of 
competency tests, the results of the competency tests used as the passing standards are the scores of competency tests that are then combined with the scores of the national theory of vocational examinations.

The skill competency obtained by students of SMKN 1 Toraja Utara for the last three years in the Accounting and Finance department is still very low. The average manual practice getting a score of 77, while the Computer Accounting Practices get an average score of 76, these numbers are almost the same as the minimum criterion score is 75, including the character value of honesty, discipline, creative thinking, as well as the value of knowledge about the vocational profession which can be seen in the national exam scores with the vocational theory test subjects. From the acquisition of these values, students' opportunity to be absorbed in the world of work and industry is $35 \%$. SMKN 1 Toraja Utara students' expertise competencies can be seen from the results of the UKK (Vocational Competency Test) and the results of the National Exam scores for the last three (3) years are shown in the following table.

Table 1.1: Average Vocational Competency Test Values for AKL Department

\begin{tabular}{|c|c|c|c|c|}
\hline \multirow{2}{*}{ Number } & Major & \multicolumn{3}{|c|}{ Year } \\
\cline { 3 - 5 } & & 2017 & 2018 & 2019 \\
\hline 1 & Practice Manual & 75,88 & 78,53 & 76,25 \\
\hline 2 & Computer Accounting Practices & 75,66 & 76,25 & 76,68 \\
\hline
\end{tabular}

Table 1.2: Average National Exam Score

\begin{tabular}{|c|c|c|c|c|}
\hline \multirow{2}{*}{ Number } & Subject to be tested & \multicolumn{3}{|c|}{ Year } \\
\cline { 3 - 5 } & & 2017 & 2018 & 2019 \\
\hline 1 & Mathematics & 30.48 & 44,11 & 39,7 \\
\hline 2 & Indonesian & 58,27 & 63,70 & 59,4 \\
\hline 3 & English & 34,77 & 42,10 & 44,1 \\
\hline 4 & Department Theory & 60,87 & 56.82 & 59,45 \\
\hline
\end{tabular}

The average value of the Vocational Theory in the National Exam 59.45 which is added to the Competency Test score in 2019 is 76.68, and the average is 68.06, and then passed, which results in the competency exam being forced and made in such a way as to obtain good grades for students to pass and be competent. Based on the description of the problem above, the research title chosen is "The Effect of Character Education and the Role of Teachers on the Competence of Students of the Institute for Accounting and Financial Skills Program at SMKN 1 Toraja Utara".

\section{RESEARCH METHODS}

This research is an ex post facto study using a quantitative approach, describing each variable and testing the research hypothesis proposed and looking for how much influence the independent variable has on the dependent variable. This study's population were teachers who taught in accounting, and financial expertise program of $S M K N$ 1 Toraja Utara, namely 31 people, and the sampling technique was saturated sampling. Collecting the data of the character education variable (X1), the teacher's role variable (X2) and the student's competence (Y) were used in the form of a questionnaire, which was presented in the form of a Likert scale using four alternative answers. The data obtained from the research results were analyzed using statistical analysis. This analysis technique is used to test the hypothesis of the magnitude of the effect than using simple regression analysis, linear regression, and multiple regression

\section{RESULT AND DISCUSSION}

Vocational Education is part of the economic sector that affects the national economy so that the quality of vocational schools reflects the quality of workers in Indonesia where quality must be built to increase HR competition in improving student competencies that must be owned during the process and after learning, namely cognitive, affective and psychomotor abilities. Jarvis argues that Education and learning aim to produce competent students. Furthermore, the competencies referred to are divided into three elements, namely; a) "Knowledge and understanding that includes academic discipline, visuomotor elements, interpersonal relationships, and moral 
The Effect of Character Education and the Role of Teachers on the Competency of Students in Accounting and Finance Program SMKN 1 Toraja Utara

values; b) Skills that include performing psychomotor procedures and interacting with other people; and c) Professional attitudes which include knowledge of professionalism, emotional commitment to professionalism and willingness to act professionally" [23].

Based on the research results on student competence, most of the 31 respondents stated that they strongly agreed with the competence of students in the dimensions of attitudes, knowledge and skills through statements as many as 33 items. Respondents who strongly agree with $58.06 \%$ or 18 out of 31 respondents and those who agree are $41.94 \%$ or 13 out of 31 respondents.

Furthermore, to determine the effect of character education variables on student competency variables, data processing was carried out using the Kolmogorov-Smirnov normality test with a significance value of $0.200>0.05$, where the normality test significance criteria said that there was an effect if the significance value was more significant than 0.05 . The Shapiro Wilk normality test shows the significant result of the Y variable is $0.968>0.05$, and the character education variable is $0.876>0.05$, this means that the data from the dependent and independent variables are normally distributed.

Proof of the effect of character education on student competence is tested for linearity with sig results. Deviation from linearity of character education is $0.641>0.05$, which means a linear relationship between character education and competence of students majoring in Accounting and Financial Institutions at SMKN 1 Toraja Utara. Likewise, the evidence is carried out through a correlation test that shows a significant result of $0.00<0.05$ and a Pearson Correlation value of 0.715 , which means a correlation between character education and student competence with the degree of strong category relationship. The results of the simple linear regression obtained a regression equation is $Y=1.092+0.658 \mathrm{X} 1$. It indicates a positive influence of the character education variable on student competence, from the results shown that good character education in schools will have a positive effect on student competence, competent students and have a character so that students will be able to compete in the world of work as needed by the industrial world. The results of this study are also in line with research which stated that the value of the character of discipline and responsibility significantly affects student success [24].

Analysis of the description of the character education program for the accounting and financial expertise of institutions at SMKN 1 Toraja Utara, on average, the respondents stated that they strongly agreed with character education to make students have a good character at school, in society and especially when students enter the world of work, because of good character. It is the main requirement for students to be accepted in the world of work so that the school must educate and teach students in every teaching and learning process to always create and instil character building, in every subject, both theoretical and practical lessons carried out in the classroom and in the laboratory.

The character education expressed is a serious, deliberate effort to help someone understand, care, and act with the core foundation of ethical values. The next definition of character education as "school-based activities that are designed together with other community institutions, to directly and systematically shape young people's behaviour by explicitly influencing the values or beliefs that are carried out directly" [25].

The most basic character education to be instilled in students is honesty, where students should not cheat during tests or if there are projects that must be done by themselves not the result of other people's work and this is also supported by the results of the questionnaire where most respondents strongly agree if the character is honest is part of character education [26]. Furthermore, with curiosity and creative thinking, students are invited to explore their curiosity and be able to pour ideas into any problems raised related to learning theory and practice, especially in completing both manual and computerized accounting tasks, completing all assignments given by the teacher, by asking, looking for references in books or via the internet. Some respondents chose to strongly agree with the curiosity of students to enter character education. Next is the character of responsibility and discipline which is one part of character education, students of SMKN 1 Toraja Utara who are vocational school students mostly learn to practice in the field and also in the laboratory, this requires students always to be responsible for completing and submitting all practical assignments on time, using equipment as appropriate and keeping the equipment and equipment used in its place, always maintaining the cleanliness and tidiness of the classroom and laboratory.

Finally, character education that must be taught to students is hard work, and students are guided not to give up in facing difficulties in understanding the material and practice provided, students are also invited to be able to compete with other school students in the form of student skill competitions so that their competencies can be displayed. 
From the results of research that has been done that there is a significant influence on the role of teachers on the competence of students majoring in accounting and financial institutions at SMKN 1 Toraja Utara which has been shown from the results of data processing using the Kolmogorov-Smirnov normality test with a significance value of $0.200>0.05$, where the criteria of significance The normality test said that there was an effect if the significance value was greater than 0.05 . The Shapiro Wilk normality test shows the significance of the $Y$ variable is $0.968>0.05$, and the teacher role variable is $0.381>0.05$. It means that the data from the dependent and independent variables are normally distributed and can be used in further tests to determine the role variables teacher's effect towards student competence.

Proof of the teacher's role on student competence is tested for linearity with sig results. Deviation from linearity of the teacher's role is $0.333>0.05$, which means a linear relationship between the teacher's role and the competence of students majoring in Accounting and Financial Institutions at SMKN 1 Toraja Utara. Likewise, the evidence is carried out through a correlation test that shows a significant result of $0.00<0.05$ and a Pearson Correlation value of 0.647 which means that there is a correlation between the teacher's role and the student's competence with the degree of strong category relationship. The results of the simple linear regression obtained a regression equation $Y$ $=1.266+0.597 \mathrm{X} 2$, which indicates a positive influence on the teacher variable's role on student competence, from the results shown that the role of a good teacher in school will have a positive influence on student competence.

The teacher role variable from the results of the descriptive analysis shows that $70.97 \%$ or most of the respondents strongly agree that the role of the teacher influences student competence, the role of the teacher as an educator must be able to show responsibility as an educator, arrive on time and have behaviour that has a positive effect on students. So that students will receive a good education. The role of the teacher as a teacher must have the skills to plan to learn in the classroom and the laboratory according to the core competencies and necessary competencies that must be taught, as well as being a facilitator to make it easier for students to learn so that it will form skilled and competent students in mastering the material provided. As teachers, teachers must also have extensive knowledge of the transferred disciplines to students, including teaching strategies and methods. As a teacher, the teacher explores students' potential and helps develop the potential as a psychological boost for students who are associated with systematic choices to develop students in achieving success in choosing jobs [27]. Teachers as trainers provide students with opportunities to apply theory in practice through project-based learning to get deep learning to improve student competence. Teachers develop manual and computerized practicum activities in the laboratory, train students to carry out practical work processes according to procedures, and train students to be independent both at school and in practice (fieldwork practice) to master the vocational knowledge that they get [27].

Testing the effect of character education and the role of teachers on student competence indicates a significant influence on the results of the $F$ test where Fount is more significant than F table $(20,798.3,33)$, with a significance value of $0,000<0.05$. Likewise, it can be seen from the coefficient of determination of 0.598 which means that $59.8 \%$ of character education and the role of the teacher affect student competence, while variations influence the remaining $40.2 \%$ in other variables not included in this study. Furthermore, the results of multiple linear regression analysis using the regression equation $\mathrm{Y}=0.599+0.472 \mathrm{X} 1+0.329 \mathrm{X} 2$ show that there is a positive effect of character education and the role of teachers on student competence.

\section{CONCLUSION}

Finally, this study ends in conclusion, from the result of and discussion of the study, it is concluded that: a) The coefficient of determination of the character education variable and competence is 0.511 or $51.1 \%$, meaning that the character education variable can explain its effect on student competency variables. Simple linear regression analysis concludes that character education has a very significant effect on student competence with a value of $t$ count greater than t table $(5,509>2,048)$, if the value of character education increases, student competence will also increase; b) The coefficient of determination of the variable character education and student competence has a value of 0.419 or $41.9 \%$, meaning that the character education variable explains its effect on student competency variables. The results of simple linear regression analysis can be concluded that character education significantly affects student competence with a value of $t$ count greater than $t$ table $(4.569>2,048)$. So if the value of the role of the teacher increases, the competence of students will also increase; and c) There is a significant effect simultaneously from the results of the F test where Fount is more significant than F table $(20,798.3,33)$, with a significance value of 
The Effect of Character Education and the Role of Teachers on the Competency of Students in Accounting and Finance Program SMKN 1 Toraja Utara

$0,000<0.05$. also from the coefficient of determination of 0.598 , which means that $59.8 \%$ of character education and teachers' role have a significant effect on the competence of students in the accounting and financial expertise program at SMKN 1 Toraja Utara.

\section{SOURCES OF FUNDING}

This research received no specific grant from any funding agency in the public, commercial, or not-for-profit sectors.

\section{CONFLICT OF INTEREST}

The author have declared that no competing interests exist.

\section{ACKNOWLEDGMENT}

None.

\section{REFERENCES}

[1] Brewer, P. D., \& Brewer, K. L. (2010). Knowledge management, human resource management, and higher education: A theoretical model. Journal of Education for Business, 85(6), 330-335.

[2] Angrave, D., Charlwood, A., Kirkpatrick, I., Lawrence, M., \& Stuart, M. (2016). HR and analytics: why HR is set to fail the big data challenge. Human Resource Management Journal, 26(1), 1-11.

[3] Tyas, E. H., \& Naibaho, L. (2021). HOTS Learning Model Improves the Quality of Education. International Journal of Research-GRANTHAALAYAH, 9(1), 176-182.

[4] Naibaho, L. (2014). The Role of Education and Culture in the Development of Character and Civilization of the Plural Indonesian Nation. Jurnal the Ary Suta Center Series on Strategic Management, 27(0), 69.

[5] Kyllonen, P. C., Lipnevich, A. A., Burrus, J., \& Roberts, R. D. (2014). Personality, motivation, and college readiness: A prospectus for assessment and development. ETS Research Report Series, 2014(1), 1-48.

[6] Nadeak, B., \& Naibaho, L. (2019). Managing Lecturers' Competence Development at Universitas Kristen Indonesia.

[7] Soulé, H., \& Warrick, T. (2015). Defining 21st century readiness for all students: What we know and how to get there. Psychology of Aesthetics, Creativity, and the Arts, 9(2), 178.

[8] Fishman, J. E. (2013). Standards of value: theory and applications. John Wiley \& Sons.

[9] Nadeak, B., \& Naibaho, L. (2018). The Description of medical students' interest and achievement on anatomy at faculty of medicine Universitas Kristen Indonesia. International Journal of Sciences: Basic and Applied Research (IJSBAR), 39(1), 121-133.

[10] Naibaho, L. (2019). The Effectiveness of Number Head Together Strategy on Improving Students'english Achievement tt XYZ School. International Journal of Research-GRANTHAALAYAH, 7(10), 362-370.

[11] Nadeak, B., Juwita, C. P., Sormin, E., \& Naibaho, L. (2020). The Relationship between Students' Critical Thinking Ability and the Use of Social Media on Learning Outcomes during the Pandemic Period Covid-19. Jurnal Konseling dan Pendidikan, 8(2), 98-104.

[12] Burnaford, G. E., Aprill, A., \& Weiss, C. (Eds.). (2013). Renaissance in the classroom: Arts integration and meaningful learning. Routledge.

[13] Li, C., Peters, G. F., Richardson, V. J., \& Watson, M. W. (2012). The consequences of information technology control weaknesses on management information systems: The case of Sarbanes-Oxley internal control reports. Mis Quarterly, 179-203.

[14] Hendriks, C. J. (2012). Integrated Financial Management Information Systems: Guidelines for effective implementation by the public sector of South Africa. South African Journal of Information Management, 14(1), $1-9$. 
[15] Power, D. (2005). Supply chain management integration and implementation: a literature review. Supply chain management: an International journal.

[16] Nadeak, B., Naibaho, L., Sormin, E., \& Juwita, C. P. (2019). Healthy Work Culture Stimulate Performance. Indian Journal of Public Health Research \& Development, 10(6), 1385-1389.

[17] Fater, K. H. (2013). Gap analysis: A method to assess core competency development in the curriculum. Nursing Education Perspectives, 34(2), 101-105.

[18] Owens, D. C., Sadler, T. D., Barlow, A. T., \& Smith-Walters, C. (2020). Student motivation from and resistance to active learning rooted in essential science practices. Research in Science Education, 50(1), 253-277.

[19] Tyas, E. H., \& Naibaho, L. (2021). HOTS Learning Model Improves the Quality of Education. International Journal of Research-GRANTHAALAYAH, 9(1), 176-182.

[20] Howieson, B. (2003). Accounting practice in the new millennium: is accounting education ready to meet the challenge?. The British Accounting Review, 35(2), 69-103.

[21] Sledgianowski, D., Gomaa, M., \& Tan, C. (2017). Toward integration of Big Data, technology and information systems competencies into the accounting curriculum. Journal of Accounting Education, 38, 81-93.

[22] Tyas, E. H., \& Naibaho, L. (2020). Building Superior Human Resources through Character Education. TEST Engineering \& Management, 83, 11864-11873.

[23] Nadeak, B., Iriani, U. E., Naibaho, L., Sormin, E., \& Juwita, C. P. (2019). Building Employees' Mental Health: The Correlation between Transactional Leadership and Training Program with Employees' Work Motivation at XWJ Factory. Indian Journal of Public Health Research \& Development, 10(6), 1373-1379.

[24] Romi, S., Lewis, R., \& Katz, Y. J. (2009). Student responsibility and classroom discipline in Australia, China, and Israel. Compare, 39(4), 439-453.

[25] Schachter, H. M., Girardi, A., Ly, M., Lacroix, D., Lumb, A. B., van Berkom, J., \& Gill, R. (2008). Effects of schoolbased interventions on mental health stigmatization: a systematic review. Child and adolescent psychiatry and mental health, 2(1), 1-14.

[26] Brannon, D. (2008). Character education: it's a joint responsibility: instilling positive character traits in children requires teachers, parents, and administrators to work together. Kappa Delta Pi Record, 44(2), 6265.

[27] Sormin, E., Julianti, K., Nadeak, B., \& Naibaho, L. (2019). Use of construction inquiri learning model to improve the interest of learning students grade XI SMA Angkasa 2 in coloid materials. PEOPLE International Journal of Social Sciences, 5(2), 908-917 